\title{
The inheritance of female colour morphs in the damselfly Ceriagrion tenellum (Odonata, Coenagrionidae)
}

\author{
JOSÉ A. ANDRÉS* \& ADOLFO CORDERO \\ Departamento de Ecoloxía e Bioloxía Animal, Universidade de Vigo, E.U.E.T. Forestal, Campus Universitario, \\ 36005 Pontevedra, Spain
}

\begin{abstract}
Female-limited polychromatism is found in many species of Odonata. In Ceriagrion tenellum (Coenagrionidae) one of the morphs is red-coloured, like the conspecific male (androchrome, erythrogastrum morph), whereas most females are red and black (typica morph) or black (melanogastrum morph). Virgin females of this species were mated in the laboratory and their progeny reared (13 crosses). Results of these crosses indicate that colour morphs are controlled by one autosomal locus with female-limited expression. A second laboratory generation (two crosses) confirmed this inheritance system. This locus has three alleles (one per phenotype) and a hierarchy of dominance: typica $>$ melanogastrum $>$ erythrogastrum. The dominance relationships of andro/ gynochrome alleles in polymorphic damselflies so far studied are discussed. The frequencies of female morphs in natural populations are highly variable, but in all cases typica females are the commonest.
\end{abstract}

Keywords: Ceriagrion tenellum, Coenagrionidae, colour morphs, female polymorphism, Odonata, sex-limited polymorphism.

\section{Introduction}

Female-limited polychromatism is found in many species of Odonata. Half the European genera of Zygoptera show this polymorphism, which is especially common in the family Coenagrionidae where $65 \%$ of the species are polymorphic (Cordero \& Andrés, 1996).

As in butterflies, where this type of polymorphism also occurs (Clarke et al., 1985), one of the female morphs is very similar to the conspecific male, whereas the other phenotypes differ in coloration. The different morphs have been given various names in the scientific literature. Because the differences among morphs involve their colour only and not their morphology, this paper will use the terminology proposed by Hilton (1987) and shortened by Cordero et al. (1998), using 'androchrome' for male-like females and 'gynochrome' for those females with a different coloration.

The genetic basis of female polychromatism is only known in three species of damselflies, all belonging to the genus Ischnura. In I. damula and I. demorsa, which are dimorphic, androchromes are homozygous for the

*Correspondence. E-mail: jaandres@uvigo.es recessive allele $(p p)$ and gynochromes are either heterozygous $\left(p^{+} p\right)$ or homozygous $\left(p^{+} p^{+}\right)$for the dominant allele of an autosomal locus with expression restricted to the female (Johnson, 1964, 1966). The same system has been proposed, although not proven, for I. elegans (Hinnekint, 1987). In I. graellsii three different morphs exist, also determined by an autosomal locus with expression restricted to the female, but in this case the system has three alleles, $p^{a}$ (androchrome), $p^{i}$ (infuscans) and $p^{\circ}$ (aurantiaca), and a hierarchy of dominance $\left(p^{a}>p^{i}>p^{\circ}\right)$ (Cordero, 1990).

Selys (1876) described four different female morphs in Ceriagrion tenellum. The androchrome morph, named erythrogastrum, whose abdomen and eyes are red as in the conspecific male, and three gynochrome morphs: melanogastrum, whose abdominal coloration is totally black in dorsal view; typica, in which the dorsum of the first two abdominal segments, most of the third and the end of the abdomen (segments IX-X) are red, and the remaining segments black; and intermedium, whose abdomen in dorsal view is mainly red, although it has apical black rings in the third to sixth segments and a small black spot in the seventh abdominal segment (Fig. 1). Papazian (1988) added a new morph, very similar to the typica morph, but having the red colour 

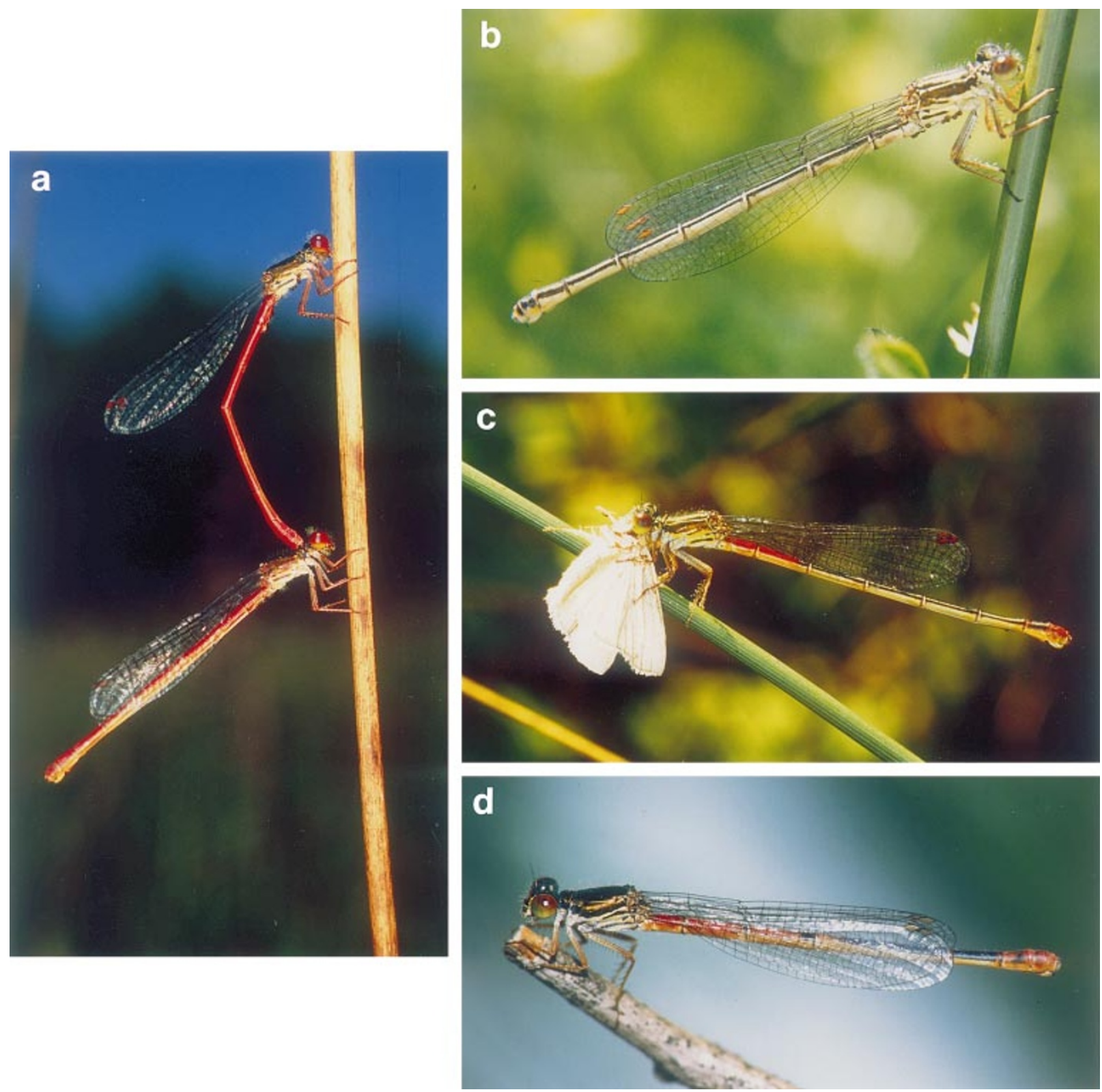

Fig. 1 Female phenotypes of Ceriagrion tenellum. (a) Androchrome (erythrogastrum) female in tandem (note its male-like coloration); (b) melanogastrum; (c) typica (photos A. Cordero); (d) intermedium (photo R. Jödicke).

more extended (the black colour begins in the base of the fourth abdominal segment), and the ninth abdominal segment more reddish than the typica morph.

In Galicia (NW Spain) we found three female phenotypes, the androchrome morph or erythrogastrum and the gynochrome morphs typica and melanogastrum. The morph intermedium seems to be absent in the populations of the Iberian Peninsula (see Ocharán, 1987; Jödicke, 1996).

A priori, the existence of these three morphs could be explained by a genetic system similar to that of I. graellsii or, because the morph intermedium is phenotypically intermediate between the androchrome and melanogastrum morphs (Fig. 1), by a system with two codominant alleles so that the androchrome females (erythrogastrum) are homozygous $\left(p^{a} p^{a}\right)$, the typica females heterozygous $\left(p^{m} p^{a}\right)$ and the melanogastrum females homozygous $\left(p^{m} p^{m}\right)$. The other two described morphs could result from the existence of two additional alleles, which are absent from our populations, or to the interaction with a modifier locus. It is also possible that some of these 'other' morphs are caused by phenotypic plasticity in the morphs erythrogastrum and typica.

(C) The Genetical Society of Great Britain, Heredity, 82, 328-335. 
This paper presents the results of laboratory crosses that allow us to deduce the genetics of the chromatic polymorphism of C. tenellum in populations of the Iberian Peninsula. Knowledge of the genetic basis of this polymorphism in Ceriagrion allows us to explore the evolutionary significance of the dominance relationships between the alleles responsible for the androchrome phenotype in four species of zygopterans. Estimates are also presented of the allelic frequencies in nine populations, which allow us to calculate levels of genetic variation for this locus.

\section{Methods}

\section{Laboratory breeding of C. tenellum}

Adults of C. tenellum were captured in June-July 1996, from different natural populations in the provinces of A Coruña and Pontevedra (NW Spain). Field-collected individuals were $0-1$ day old ('tenerals'), showing incompletely developed colour and a vitreous shine in the wings. Teneral animals are not sexually mature, and are therefore virgin. Individuals were marked with a number on the wings and raised in four insectaries sized $50 \times 50 \times 50$ (or 70) $\mathrm{cm}$ with numerous wooden sticks as perches. The insectaries were internally lined with aluminium foil, to avoid escape reactions (Johnson, 1965; Cordero, 1990; Cooper et al., 1996). Culture bottles of Drosophila melanogaster and D. buzzatii were added to provide food. Occasionally, because of high initial mortality, some individuals were fed by hand twice a day during the maturation period.

The same insectaries were used to obtain matings. Receptive females (9-11 days old) were introduced to insectaries containing sexually mature males (6-7 days old). Males competed for introduced females to produce the first laboratory progenies. However, to obtain the second-generation laboratory progenies, males and females were selected, bearing in mind their probable genotype, and introduced in pairs to the insectaries. To avoid the possibility of a female mating with more than one male, all matings were continually observed.

In the wild, C. tenellum females lay eggs in tandem (the male holds the female's prothorax with his anal appendices, see Fig. 1a) with their mate, immediately after copulation, inserting the eggs inside plant tissue (endophytic oviposition), especially in leaves and floating stems of Potamogeton. To simulate these conditions, mated females were introduced into an aquarium with $0.5 \mathrm{~cm}$ of water, containing different oviposition substrates. Artificial oviposition substrates (filter paper, chromatography paper and polystyrene sheets) failed to elicitate oviposition in most females, unlike Ischnura (Cordero, 1990). The best results were obtained using small fragments of Trifolium repens and Tradescantia fluminensis. Whenever possible the latter was used, as it remains alive during the period of maturation of the eggs, avoiding the development of fungi that could affect their viability.

Larvae emerged after about 1 month and were maintained in plastic boxes, with spring water and strips of filter paper as perches. Larvae were fed with nauplii of Artemia salina (Cordero, 1990). Upon reaching a size of about $7-8 \mathrm{~mm}$, they were fed with Tubifex and Lumbriculus. When larvae reached the last instar stage, several sticks were introduced as emergence substrates.

Using this method, 683 females were obtained with a generation interval of 9-11 months. All females were assigned to their phenotype a few hours after emergence.

Observed and expected frequencies were compared using $\chi^{2}$-tests. Allelic frequencies and variances were calculated, on the assumption that the populations are in Hardy-Weinberg equilibrium, by maximum likelihood estimates (see Hedrick, 1985). Quantification of the genetic variability in different populations involved estimating the heterozygosity $(H)$, current number of alleles $(n)$ and effective number of alleles $\left(n_{\mathrm{e}}\right)$ in each population. The sample variance of the heterozygosity was calculated following Nei \& Roychoudhury (1974).

\section{Results and discussion}

Segregation of female phenotypes in the first progenies of $C$. tenellum is shown in Table 1 . The results indicate that females can produce offspring of at least two different phenotypes and that when two phenotypes are present they segregate in proportions which do not differ significantly from the ratios $3: 1$ or $1: 1$. These results are compatible with the hypothesis that the inheritance of the polymorphism is by a single autosomal locus. Ratios of 3:1 were obtained in four progenies from typica females. Such results are incompatible with the presence of two codominant alleles, and suggest that polymorphism is controlled by an autosomal locus with three alleles with complete and hierarchical dominance.

To confirm this hypothesis, five second-generation laboratory crosses were carried out, although unfortunately only two females laid eggs. The results are presented in Table 2. The simplest hypothesis to explain the segregations observed in both progenies postulates the existence of an autosomal locus with three alleles and hierarchical dominance $\left(p^{t}>p^{m}>p^{a}\right)$. Under this hypothesis, the typica morph has three possible genotypes $\left(p^{t} p^{t}, p^{t} p^{m}, p^{t} p^{\mathrm{a}}\right)$, the morph melanogastrum two $\left(p^{m} \mathrm{p}^{m}, p^{m} p^{\mathrm{a}}\right)$, and the androchrome morph only one genotype $\left(p^{a} p^{a}\right)$.

As was the case for I. graellsii (Cordero, 1990), the sex ratio does not differ significantly from $1: 1$ in any of the 
progenies. This rejects the possibility that some genotypes are lethal in males.

The occurrence of additional alleles, which are absent from the populations in the present study, is the most plausible hypothesis explaining the existence of two more female morphs in this species. Nevertheless, the existence of a modifier locus could also explain the morph intermedium of Selys (1876), very similar to the

Table 1 Frequencies (percentage) of female phenotypes in the first laboratory generations of Ceriagrion tenellum. Number of individuals (in parentheses) and expected frequencies given the null hypothesis of one autosomal locus with three alleles and complete dominance (in italics). Parental genotypes were deduced from their progenies

\begin{tabular}{|c|c|c|c|c|c|c|c|c|}
\hline \multirow[b]{2}{*}{ Cross code } & \multicolumn{2}{|c|}{ Parental genotypes } & \multirow[b]{2}{*}{$\begin{array}{l}\text { Percentage } \\
\text { of males }\end{array}$} & \multicolumn{3}{|c|}{ Female phenotype } & \multirow[b]{2}{*}{$\chi_{1}^{2}$} & \multirow[b]{2}{*}{$P$} \\
\hline & $\begin{array}{l}\text { Female } \\
\text { genotype }\end{array}$ & $\begin{array}{l}\text { Male } \\
\text { genotype }\end{array}$ & & a & $\mathrm{t}$ & $\mathrm{m}$ & & \\
\hline \multicolumn{9}{|l|}{ erythrogastrum } \\
\hline $\mathrm{f} \mathrm{A} \times \mathrm{m} 1$ & $p^{a} p^{a}$ & $p^{t} p^{a}$ & 51.7 & $\begin{array}{l}56.5(39) \\
50.0\end{array}$ & $\begin{array}{l}43.5(30) \\
50.0\end{array}$ & $0.0(0)$ & 2.291 & 0.130 \\
\hline $\mathrm{f} B \times \mathrm{m} 2$ & $p^{a} p^{a}$ & $p^{t} p^{a}$ & 44.7 & $\begin{array}{l}54.8(23) \\
50.0\end{array}$ & $\begin{array}{l}45.2(19) \\
50.0\end{array}$ & $0.0(0)$ & 0.381 & 0.537 \\
\hline typica & & & & & & & & \\
\hline $\mathrm{f} \mathrm{C} \times \mathrm{m} 3$ & $p^{t} p^{m} / p^{t} p^{a}$ & $p^{t} p^{m} / p^{t} p^{a}$ & 55.0 & $0.0(0)$ & $\begin{array}{l}76.6(59) \\
75.0\end{array}$ & $\begin{array}{l}23.4(18) \\
25.0\end{array}$ & 0.010 & 0.752 \\
\hline $\mathrm{f} \mathrm{D} \times \mathrm{m} 4$ & $p^{t} p^{t}$ & $p^{t} p^{m}$ & 53.4 & $0.0(0)$ & $100.0(6)$ & $0.0(0)$ & - & - \\
\hline $\mathrm{f} E \times \mathrm{m} 5$ & $p^{t}-$ & $p^{t}-$ & 40.0 & $0.0(0)$ & $100.0(12)$ & $0.0(0)$ & - & - \\
\hline $\mathrm{f} F \times \mathrm{m} 4$ & $p^{t} p^{m} / p^{t} p^{a}$ & $p^{t} p^{m}$ & 57.1 & $0.0(0)$ & $\begin{array}{l}81.8(9) \\
75.0\end{array}$ & $\begin{array}{l}18.2(2) \\
25.0\end{array}$ & $0.112^{*}$ & 0.738 \\
\hline $\mathrm{f} \mathrm{G} \times \mathrm{m} 1$ & $p^{t} p^{m}$ & $p^{t} p^{a}$ & 65.4 & $0.0(0)$ & $\begin{array}{l}70.0(7) \\
75.0\end{array}$ & $\begin{array}{l}30.0(3) \\
25.0\end{array}$ & $0.133^{*}$ & 0.715 \\
\hline $\mathrm{f} \mathrm{H} \times \mathrm{m} 4$ & $p^{m} p^{m} / p^{t} p^{a}$ & $p^{t} p^{m}$ & 52.5 & $0.0(0)$ & $\begin{array}{l}63.6(35) \\
75.0\end{array}$ & $\begin{array}{l}36.4(12) \\
25.0\end{array}$ & 1.172 & 0.279 \\
\hline melanogastrum & & & & & & & & \\
\hline $\mathrm{f} I \times \mathrm{m} 6$ & $p^{m}-$ & $p^{m}-$ & 51.2 & $0.0(0)$ & $0.0(0)$ & $100.0(54)$ & - & - \\
\hline $\mathrm{f} \mathbf{J} \times \mathrm{m} 7$ & $p^{m}-$ & $p^{m}-$ & 56.2 & $0.0(0)$ & $0.0(0)$ & $100.0(28)$ & - & - \\
\hline $\mathrm{f} \mathrm{K} \times \mathrm{m} 4$ & $p^{m} p^{m} / p^{m} p^{a}$ & $p^{t} p^{m}$ & 50.3 & $0.0(0)$ & $\begin{array}{l}48.7(39) \\
50.0\end{array}$ & $\begin{array}{l}51.3(41) \\
50.0\end{array}$ & 0.050 & 0.823 \\
\hline $\mathrm{f} \mathrm{L} \times \mathrm{m} 8$ & $p^{m} p^{m} / p^{m} p^{a}$ & $p^{t} p^{m}$ & 51.5 & $0.0(0)$ & $\begin{array}{l}61.7(29) \\
50.0\end{array}$ & $\begin{array}{l}38.3(18) \\
50.0\end{array}$ & 2.574 & 0.109 \\
\hline $\mathrm{f} \mathrm{M} \times \mathrm{m} 4$ & $p^{m} p^{m} / p^{m} p^{a}$ & $p^{t} p^{m}$ & 48.6 & $0.0(0)$ & $\begin{array}{l}58.2(32) \\
50.0\end{array}$ & $\begin{array}{l}41.8(23) \\
50.0\end{array}$ & 1.473 & 0.225 \\
\hline $\mathrm{f} \mathrm{N} \times \mathrm{m} 9$ & $p^{m}-$ & $p^{m}-$ & 43.9 & $0.0(0)$ & $0.0(0)$ & $100.0(37)$ & - & - \\
\hline
\end{tabular}

a, androchrome; t, typica; $\mathrm{m}$, melanogastrum.

Table 2 Percentage of female phenotypes in the second laboratory generation of Ceriagrion tenellum: number of individuals (in parentheses) and expected frequencies given the null hypothesis of one autosomal locus with three alleles and complete dominance (in italics). The letter that identifies each individual in a cross is the code of the parental female of the first generation. Parental genotypes were deduced from their progenies

\begin{tabular}{|c|c|c|c|c|c|c|c|c|}
\hline \multirow[b]{2}{*}{ Cross code } & \multicolumn{2}{|c|}{ Parental genotypes } & \multirow[b]{2}{*}{$\begin{array}{l}\text { Percentage } \\
\text { of males }\end{array}$} & \multicolumn{3}{|c|}{ Female phenotype } & \multirow[b]{2}{*}{$\chi_{1}^{2}$} & \multirow[b]{2}{*}{$P$} \\
\hline & $\begin{array}{l}\text { Female } \\
\text { genotype }\end{array}$ & $\begin{array}{l}\text { Male } \\
\text { genotype }\end{array}$ & & $\mathrm{a}$ & $\mathrm{t}$ & $\mathrm{m}$ & & \\
\hline $\begin{array}{l}\text { melanogastrum } \\
\mathrm{f} \mathrm{G} 1 \times \mathrm{m} \mathrm{B} 1\end{array}$ & $p^{m} p^{a}$ & $p^{a} p^{a}$ & 54.4 & $41.8(23)$ & $0.0(0)$ & $57.2(32)$ & 1.472 & 0.224 \\
\hline $\begin{array}{l}\text { erythrogastrum } \\
\text { f A } 1 \times \mathrm{m} \mathrm{I} 1\end{array}$ & $p^{a} p^{a}$ & $p^{m} p^{a}$ & 46.8 & $\begin{array}{l}45.8(27) \\
50.0\end{array}$ & $0.0(0)$ & $\begin{array}{l}54.2(32) \\
50.0\end{array}$ & 0.423 & 0.515 \\
\hline
\end{tabular}

a, androchrome; t, typica; m, melanogastrum.

(c) The Genetical Society of Great Britain, Heredity, 82, 328-335. 
androchrome morph, and the morph described by Papazian (1988), similar to the typica morph, if phenotypic expression varies depending on the allele present at the modifier locus. It is also possible that these morphs result from phenotypic plasticity of the morphs erythrogastrum and typica.

Except in I. graellsii, in all the studied coenagrionids the androchrome allele is recessive. Generally, it is assumed for a polymorphic locus that the ancestral allele is recessive to those that have evolved subsequently (Clarke et al., 1985). This principle, known as Haldane's sieve (Clarke et al., 1985), states that a new dominant allele can be fixed rapidly in the population if it has a selective advantage (Haldane, 1924), whereas the probability of establishment for a recessive advantageous allele is much lower (Turner, 1983). Only when populations are small and the selective advantage of the new mutation is small, does the probability of establishment of a recessive allele become practically similar to that of dominant alleles because, in such cases, random drift plays the predominant role in establishing new mutants (Clarke et al., 1985).

Assuming Haldane's sieve, the females of I. damula, I. demorsa and $C$. tenellum would be ancestrally similar to the males, evolving the sexual dimorphism subsequently. The case of I. graellsii suggests the possibility that this polymorphism evolved independently in different coenagrionids, which suggests an adaptive value for this trait. However, Haldane's sieve is probabilistic and does not reject the possibility that recessive morphs have evolved subsequently to the dominant. The study of the inheritance of similar polymorphisms in other Coenagrionidae is necessary to discriminate between these two hypotheses.

\section{Genetic variability}

To examine allelic variability, it must be assumed that the populations are in Hardy-Weinberg equilibrium because, unfortunately, we do not have independent estimates of the observed frequencies. The observed and expected allelic frequencies are presented in Table 3. In all studied Galician populations, the most abundant females are typica $(52-74 \%)$. The melanogastrum morph is always the second most abundant morph (12-47\%), excepting the Maus de Salas population which has the maximum frequency of erythrogastrum (0-27\%). All morphs are present in all the populations with the exception of the Pozo de Lago and Barra populations where no androchrome females have been found. Populations where phenotypic frequencies were estimated on different dates do not show intrapopulation variation (A Castiñeira, $\chi_{4}^{2}=3.79$, NS; As Graveiras, $\left.\chi_{8}^{2}=7.80, \mathrm{NS}\right)$.
The interpopulation variation of the phenotypic frequencies in the Galician populations (excluding cases where observed frequencies are less than five) revealed significant differences $\left(\chi_{8}^{2}=54.46, P<0.001\right.$; Table 3$)$. Estimates of the genetic variability for this locus in the Galician populations were based on expected allele frequencies. Table 4 shows the heterozygosity value and the numbers of current and effective alleles for each population. These results show that the expected percentage of heterozygous females is high (43-67\%) in all populations. On the other hand, the effective number of alleles is close to the number of alleles present. These data contrast with those obtained by Jödicke (1996) who has studied the proportion of the different phenotypes in two populations in Ullals, Tarragona (25\% typica, $75 \%$ erythrogastrum, $n=20$ ) and La Canaleta, Tarragona ( $20 \%$ melanogastrum, $80 \%$ typica, $n=10)$, both in NE Spain. The frequency of androchrome females varies from practically $0 \%$ in populations like Barra or Pozo de Lago (NW Spain) and Castel Porziano (Rome, Italy; $n=125$; Carini, 1995) to $97.5 \%$ in some German populations (R. Jödicke, pers. comm.).

The coexistence of two or three female morphs, at different population frequencies has been explained in terms of reproductive isolation (Johnson, 1975), frequency-dependent selection (Robertson, 1985) and density-dependent selection (Hinnekint, 1987), but all these adaptive hypotheses are unable to explain the existence of more than one gynochrome morph. It is also possible that this polymorphism is neutral to selection and random factors are the most important force in its maintenance (Fincke, 1994a,b).

According to Johnson (1975), the polymorphism is mantained because gynochromes are commonly involved in matings with males of other species but androchromes are not. After two years of field work and 494 examined mating pairs, only one interspecific copulation was found. For this reason this hypothesis is not applicable to C. tenellum. Robertson (1985) proposed that if mating is long and costly (up to $2.5 \mathrm{~h}$ in $C$. tenellum) and a single mating is enough to fertilize all the eggs that a female could lay throughout her life, the androchrome coloration would be advantageous for 'deceiving' males, thus avoiding unnecessary matings. Under this 'intraspecific mimicry' hypothesis, androchrome females dedicate more time to feeding and oviposition but they suffer a greater predation risk because of their more conspicuous coloration. Hinnekint (1987) proposed that the density of the population is the mechanism that maintains the polymorphism. At high densities the androchrome morph would have an advantage through not being disturbed by males, but it would suffer a balancing disadvantage of reduced mating success at low male densities. 
Although C. tenellum males are unable to distinguish between androchrome females and other males, no differences in the survival probability of the morphs were found (Andrés, 1998) as Robertson's hypothesis assumes. This result suggests that mortality factors are independent of female coloration in this species.

Table 3 Frequencies of phenotypes and alleles with standard errors in different Galician (NW Spain) populations of Ceriagrion tenellum

\begin{tabular}{|c|c|c|c|c|c|c|c|c|c|c|c|}
\hline \multirow[b]{2}{*}{ Population } & \multicolumn{5}{|c|}{ Phenotypic frequencies $(\%)$} & \multicolumn{6}{|c|}{ Allelic frequencies } \\
\hline & Date & $n$ & $\mathrm{a}$ & $\mathrm{t}$ & $\mathrm{m}$ & $p^{t}$ & (SE) & $p^{m}$ & (SE) & $p^{a}$ & (SE) \\
\hline $\begin{array}{l}\text { Candamil, } \\
\text { Lugo }\end{array}$ & June 1990 & 26 & 11.60 & 69.2 & 19.2 & 0.445 & $(0.0067)$ & 0.215 & $(0.0102)$ & 0.339 & $(0.1143)$ \\
\hline $\begin{array}{l}\text { Barra, } \\
\text { Pontevedra }\end{array}$ & Aug-Sep 1996 & 34 & 0.00 & 73.7 & 26.3 & 0.485 & $(0.0126)$ & 0.514 & $(0.0193)$ & - & - \\
\hline $\begin{array}{l}\text { Goián, } \\
\text { Pontevedra }\end{array}$ & June 1996 & 16 & 18.75 & 56.25 & 25.0 & 0.338 & $(0.0234)$ & 0.228 & $(0.0359)$ & 0.433 & $(0.1645)$ \\
\hline $\begin{array}{l}\text { Maus de Salas, } \\
\text { Ourense }\end{array}$ & July-Aug 1997 & 152 & 27.00 & 61.2 & 11.8 & 0.376 & $(0.0025)$ & 0.103 & $(0.0044)$ & 0.519 & $(0.0584)$ \\
\hline As Graveiras, & June 1990 & 54 & 14.80 & 53.7 & 31.5 & 0.319 & $(0.0004)$ & 0.295 & $(0.0067)$ & 0.384 & $(0.0844)$ \\
\hline \multirow[t]{2}{*}{ A Coruña } & July-Aug 1995 & 525 & 18.70 & 51.6 & 29.7 & 0.304 & $(0.0006)$ & 0.263 & $(0.0013)$ & 0.432 & $(0.0286)$ \\
\hline & July-Aug 1997 & 221 & 14.00 & 58.4 & 27.6 & 0.354 & $(0.0017)$ & 0.270 & $(0.0028)$ & 0.374 & $(0.0411)$ \\
\hline \multirow{5}{*}{$\begin{array}{l}\text { A Castiñeira, } \\
\text { A Coruña }\end{array}$} & August 1995 & 657 & 12.50 & 61.9 & 25.6 & 0.383 & $(0.0005)$ & 0.263 & $(0.0011)$ & 0.353 & $(0.0231)$ \\
\hline & June 1996 & 662 & 9.90 & 59.5 & 30.6 & 0.363 & $(0.0005)$ & 0.322 & $(0.0011)$ & 0.313 & $(0.0217)$ \\
\hline & July 1996 & 263 & 10.30 & 64.2 & 25.5 & 0.402 & $(0.0015)$ & 0.277 & $(0.0025)$ & 0.320 & $(0.0349)$ \\
\hline & August 1996 & 362 & 11.90 & 60.2 & 27.9 & 0.369 & $(0.0010)$ & 0.286 & $(0.0018)$ & 0.344 & $(0.0308)$ \\
\hline & July-Aug 1997 & 158 & 11.40 & 64.6 & 24.0 & 0.404 & $(0.0025)$ & 0.257 & $(0.0040)$ & 0.337 & $(0.0462)$ \\
\hline $\begin{array}{l}\text { Pozo de Lago, } \\
\text { Ourense }\end{array}$ & July 1998 & 43 & 0.00 & 53.5 & 46.5 & 0.318 & $(0.0031)$ & 0.682 & $(0.0089)$ & - & - \\
\hline $\begin{array}{l}\text { O Castelo, } \\
\text { A Coruña }\end{array}$ & July 1998 & 82 & 12.20 & 63.4 & 24.4 & 0.395 & $(0.0019)$ & 0.256 & $(0.0024)$ & 0.349 & $(0.0027)$ \\
\hline $\begin{array}{l}\text { Lagoa Catoián, } \\
\text { A Coruña }\end{array}$ & July 1998 & 53 & 9.40 & 62.3 & 28.3 & 0.386 & $(0.0029)$ & 0.307 & $(0.0043)$ & 0.307 & $(0.0043)$ \\
\hline
\end{tabular}

a, androchromes; $\mathrm{m}$, melanogastrum; $\mathrm{t}$, typica; $n$, number of sampled females.

Table 4 Estimated heterozygosity $(H)$ and its sample variance $\mathrm{V}(H)$, number of alleles $(n)$ and number of effective alleles $\left(n_{\mathrm{e}}\right)$ for the locus responsible for the chromatic polymorphism in different Galician populations of Ceriagrion tenellum

\begin{tabular}{lllccc}
\hline Population & \multicolumn{1}{c}{ Date } & $H$ & $\mathrm{~V}(H)$ & $n$ & $n_{\mathrm{e}}$ \\
\hline Candamil, Lugo & June 1990 & 0.640 & 0.0007 & 3 & 2.778 \\
Barra, Pontevedra & Aug-Sep 1996 & 0.499 & 0.0001 & 2 & 1.998 \\
Goián, Pontevedra & June 1996 & 0.645 & 0.0011 & 3 & 2.822 \\
Maus de Salas, Ourense & July-Aug 1997 & 0.577 & 0.0002 & 3 & 2.366 \\
As Graveiras, A Coruña & June 1990 & 0.662 & $9.1 \times 10^{-5}$ & 3 & 2.960 \\
& July-Aug 1995 & 0.651 & $2.1 \times 10^{-5}$ & 3 & 2.867 \\
A Castiñeira, A Coruña & July-Aug 1997 & 0.660 & $1.9 \times 10^{-5}$ & 3 & 2.946 \\
& August 1995 & 0.658 & $7.3 \times 10^{-6}$ & 3 & 2.931 \\
& June 1996 & 0.665 & $1.7 \times 10^{-6}$ & 3 & 2.987 \\
& July 1996 & 0.658 & $2.2 \times 10^{-5}$ & 3 & 2.929 \\
Pozo de Lago, Ourense & August 1996 & 0.663 & $7.1 \times 10^{-6}$ & 3 & 2.967 \\
O Castelo, A Coruña & July-Aug 1997 & 0.655 & $4.7 \times 10^{-5}$ & 3 & 2.905 \\
Lagoa Catoián, A Coruña & July 1998 & 0.434 & 0.0013 & 2 & 1.766 \\
\hline
\end{tabular}

(C) The Genetical Society of Great Britain, Heredity, 82, 328-335. 
On the other hand, if the density-dependent hypothesis is correct, the frequency of androchrome females should be greater in high density populations. The data presented here do not support this hypothesis because no correlation was found between the density of males and androchrome frequency in nine different Galician populations (unpubl. data).

Morph frequencies in C. tenellum are much more variable between populations than in other studied coenagrionids (Table 3). This could be explained by founder effects and random genetic drift or by the existence of a relationship between ecological factors and the frequencies of the morphs.

In 1995, 1522 individuals were marked at a large wetland and none of them was found in the closest conspecific population ( $3 \mathrm{~km}$ away; Andrés \& Cordero, 1998). This result suggests that in this species gene flow is low and the existence of genetic drift associated with founder effects cannot be ruled out. Furthermore, preliminary results suggest that there are no trade-offs in fitness correlates between morphs, nor fluctuating (frequency- or density-dependent) fitness of the morphs at the frequencies of the studied population (A Castiñeira, Galicia, NW Spain; Andrés, 1998).

It is possible that in C. tenellum the relative importance of random factors in the maintenance of the coloration polymorphism is greater than in other polymorphic coenagrionids such as I. graellsii, I. elegans and Nehalennia irene (Cordero, 1992; Forbes et al., 1995; Cordero et al., 1998), where the density of the populations seems to be a major factor determining the frequency of the morphs.

In conclusion, there are three aspects that need to be clarified in future work. First, the relative importance of random and selective factors in the maintenance of this polymorphism. Secondly, given the diversity in ecology and behaviour of coenagrionids, the relative advantages of the different morphs probably differ between species and in different ecological conditions for each species. Finally, new adaptive hypotheses are needed to explain the existence of more than one gynochrome morph. Differential fecundity, differential survivorship or competitive abilities during the larval or immature stages, or the effect of male genotype at the $p$ locus on male fitness are some possibilities (Cordero \& Andrés, 1996).

\section{Acknowledgements}

Many thanks to Reinhard Jödicke, who kindly helped with literature searching and provided the slide of the intermedium female for Fig. 1(d). The manuscript was greatly improved by the comments of two anonymous referees.

\section{References}

ANDRÉs, J. A. 1998. Polimorfismo y selección sexual en Ceriagrion tenellum (Odonata). Ph.D. Thesis, Universidad de Vigo, Vigo.

ANDRÉS, J. A. AND CORDERO, A. 1998. Effects of water mites on the damselfly Ceriagrion tenellum. Ecol. Entomol., 23, 103109.

CARINI, A. 1995. Compartamento riproductive e comportamento individuale di Ceriagrion tenellum (De Villers, 1789), con particolare riferimento alla competizione sessuale (Insecta, Odonata). M.Sc. Thesis, University of Rome 'La Sapienza', Rome.

CLARKE, C., ClARKE, F. M. M., GILL, A. C. L. AND TURNER, J. R. G. 1985. Male-like females, mimicry and transvestism in butterflies (Lepidoptera, Papilionidae). Syst. Entomol., 10, 257-283.

COOPER, G., HOLLAND, P. W. H. AND MiLler, P. L. 1996. Captive breeding of Ischnura elegans (Vander Linden): Observations on longevity, copulation and oviposition (Zygoptera: Coenagrionidae). Odonatologica, 25, 261-273.

CORDERO, A. 1990. The inheritance of female polymorphism in the damselfly Ischnura graellsii (Rambur) (Odonata: Coenagrionidae). Heredity, 64, 341-346.

CORDERO, A. 1992. Density-dependent mating success and colour polymorphism in females of the damselfly Ischnura graellsii (Odonata: Coenagrionidae). J. Anim. Ecol., 61, 769-780.

CORDERO, A. AND ANDRÉS, J. A. 1996. Colour polymorphism in odonates: females that mimic males? J. Br. Dragonfly Soc., 12, 50-60.

CORDERo, A., SANTOLAMAZZA-CARBONE, S. AND UTZERI, C. 1998. Mating opportunities and mating costs are reduced in androchrome female damselflies, Ischnura elegans (Odonata). Anim. Behav., 55, 185-197.

FINCKE, O. M. 1994a. Female colour polymorphism in damselflies: Failure to reject the null hypothesis. Anim. Behav., 47, 1249-1266.

FINCKE, O. M. 1994b. On the difficulty of detecting densitydependent selection on polymorphic females of the damselfly Ischnura graellsii: failure to reject the null. Evol. Ecol., 8, 328-329.

FORBES, M. R. L., RICHARDSON, J. M. L. AND BAKER, R. L. 1995. Frequency of female morphs is related to an index of male density in the damselfly, Nehalennia irene (Hagen). Can. J. Zool., 75, 253-260.

HALDANE, J. B. S. 1924. A mathematical theory of natural and artificial selection, part I. Trans. Camb. Phil. Soc., 23, 19-41.

HEDRICK, P. W. 1985. Genetics of Populations. Jones \& Barlett, Boston, MA.

HILTON, D. F. J. 1987. A terminology for females with color patterns that mimic males. Ent. News, 98, 221-223.

HINNEKINT, B. O. N. 1987. Population dynamics of Ischnura e. elegans (Vander Linden) (Insecta: Odonata) with special reference to morphological colour changes, female polymorphism, multiannual cycles and their influence on behaviour. Hydrobiologia, 146, 3-31.

JöDICKE, R. 1996. Die Odonatenfauna der Provinz Tarragona (Calalunya, Spanien). In: Jödicke, R. (ed.) Studies on Iberian 
Dragonflies: Advances in Odonatology, (Suppl. 1), pp 77-111. Ursus Scientific Publishers, Bilthoven, Netherlands.

JOHNSON, C. 1964. The inheritance of the female polymorphism in the damselfly, Ischnura damula. Genetics, 49, 513-519.

JOHNSON, C. 1965. Mating and oviposition of damselflies in the laboratory. Can. Ent., 97, 321-326.

Johnson, C. 1966. Genetics of female dimorphism in Ischnura demorsa. Heredity, 21, 453-459.

JOHNSON, C. 1975. Polymorphism and natural selection in Ischnuran damselflies. Evol. Theory, 1, 81-90.

NEI, M. AND ROYCHOUdHURY, A. K. 1974. Sampling variances and genetic distance. Genetics, 76, 379-390.

oCharÁn, F. J. 1987. Los odonatos de Asturias y España: Aspectos sistemáticos y faunísticos. Ph.D. Thesis, Universidad de Oviedo, Oviedo.
PAPAZIAN, M. 1988. A propos de Ceriagrion tenellum (de Villers, 1789) observé en Corse (Odonata Zygoptera: Coenagrionidae). Martinia, 4, 17-18.

ROBERTSON, H. M. 1985. Female dimorphism and mating behaviour in a damselfly, Ischnura ramburi: females mimicking males. Anim. Behav., 33, 805-809.

SELYS, L. E. 1876. Synopsis des agrionnes, 5e légion: Agrion (Suite). Bull. Acad. r. Belg., 5, 712-714.

TURNER, J. R. G. 1983. Mimetic butterflies and punctuated equilibria: some old light on a new paradigm. Biol. J. Linn. Soc., 20, 277-300. 